\title{
MORPHOLOGICAL AND MICROARRAY ANALYSIS OF HUMAN FIBROBLASTS CULTURED ON NANOCOLUMNS PRODUCED BY COLLOIDAL LITHOGRAPHY
}

\author{
Matthew J. Dalby ${ }^{1 *}$, Mathis O. Riehle ${ }^{1}$, Duncan S. Sutherland ${ }^{2}$, Hossein Agheli ${ }^{2}$ and Adam S.G. Curtis ${ }^{1}$ \\ ${ }^{1}$ Centre for Cell Engineering, Institute of Biomedical and Life Sciences, University of Glasgow, Glasgow, UK and \\ ${ }^{2}$ Department of Applied Physics, Chalmers University of Technology, Gothenburg, Sweden
}

\begin{abstract}
The environment around a cell during in vitro culture is unlikely to mimic those in vivo. Preliminary experiments with nanotopography have shown that nanoscale features can strongly influence cell morphology, adhesion, proliferation and gene regulation, but the mechanisms mediating this cell response remain unclear. In this study a well defined nanotopography, consisting of $100 \mathrm{~nm}$ wide and $160 \mathrm{~nm}$ high cylindrical columns, was used in fibroblast culture. In order to build on previously published morphological data that showed changes in cell spreading on the nanocolumns, in this study gene regulation was monitored using a 1718 gene microarray. Transmission electron microscopy, fluorescent observation of actin and Rac and area quantification have been used to re-affirm the microarray observations. The results indicate that changes in cell spreading correlate with a number of gene up- and down-regulations as will be described within the manuscript.
\end{abstract}

Key Words: Nanobioscience, nanotopography, microarray.

*Address for correspondence:

Matthew J. Dalby

Centre for Cell Engineering

Institute of Biomedical and Life Sciences

Joseph Black Building

University of Glasgow, Glasgow, G12 8QQ, UK

Telephone Number: +44 (0)141 3398855 (ext. 0838)

FAX Number: +44 (0)1413303730

E-mail: m.dalby@bio.gla.ac.uk

\section{Introduction}

It has been known for almost one hundred years that cells will react to the topographic structure of their environment, and in 1952 Weiss and Garber first used the term contact guidance (Carrel and Burrows, 1911; Weiss and Garber 1952). Advances in micro-technology have allowed researchers in more recent history to produce accurate micro-scale substrates upon which to study the influence of topographic structures on cells. The effects of microtopography have been extensively studied and include changes in cell adhesion, contact guidance, cytoskeletal organisation, apoptosis, macrophage activation and gene expression (Clark et al., 1987, 1990; Wojciack-Stothard et al., 1995; Britland et al., 1996; Chen et al., 1997; Dalby et al., 2003). When considering research topics such as tissue engineering, where the focus is to restore the function of damaged tissue, these are all key processes in tissue survival.

The mechanism by which cells react to topography and the routes to signal transduction, however, remain unclear. In a recent study, we cultured fibroblasts on microgrooved surface topographies and morphological and gene expression data were analysed. As expected, the cells aligned along the grooves, demonstrating contact guidance. Cell nuclei were also seen to elongate along the grooves becoming longer and narrower. Using microarray technology, the study showed a large number of gene changes after 24 hours (average shift of 129\%) and 5 days (average shift of $-88 \%$ ) compared to flat controls. These changes were in the areas of cytoskeleton, cell signalling, extracellular matrix regulation and proliferation (Dalby et al., 2003).

Nanoscale topography may be of great importance when considering how cells respond to their environment, and certainly appears to alter significantly the morphology of endothelial cells, epithelial cells, epitenon cells, macrophages, osteoblasts and fibroblasts (Dalby et al., 2002a,b, 2004a,b,c,d; Wood et al., 2002; Rice et al., 2003; Andersson et al., 2003a,b,c).

In this manuscript a nanotopography produced by colloidal lithography will be considered. Previous cellbased studies with this topography have shown changes in morphology, endocytosis, filopodia production, migration and cytokine release. For a brief overview of the breadth of cell responses observed so far please see Table 1.

As has been used in our previous studies (Dalby et al., 2004a,b,c), nanocolumns (160-170 nm high) were employed. To fabricate the topography, a dispersed monolayer of nanoscale colloids were self-assembled on 
Table 1. An overview of the literature concerning cell reaction to single-chemistry structures derived from colloids.

\begin{tabular}{|c|c|c|c|c|}
\hline Cell type & Topography shape & Methods & Results & Reference \\
\hline $\begin{array}{l}\text { Primary rat } \\
\text { epitenon cells }\end{array}$ & $50 \mathrm{~nm}$ diameter columns & - SEM & $\begin{array}{l}\text { Direct interactions between the } \\
\text { cells and the columns were seen at } \\
\text { the peripheral cell membrane }\end{array}$ & $\begin{array}{l}\text { Wood et al. } \\
(2002)\end{array}$ \\
\hline $\begin{array}{l}\text { Rat pancreatic } \\
\text { epithelial cells } \\
(\text { AR4-2J) }\end{array}$ & $\begin{array}{l}\text { Four types of column with diameters of: } \\
58,91,111 \text { and } 166 \mathrm{~nm}\end{array}$ & $\begin{array}{l}\text { - Quantitative morpho- } \\
\text { logical measurements } \\
\text { after fluorescent actin } \\
\text { staining }\end{array}$ & $\begin{array}{l}\text { It was observed that the larger the } \\
\text { feature, the more spread the cells } \\
\text { became }\end{array}$ & $\begin{array}{l}\text { Andersson et al. } \\
\text { (2003a). }\end{array}$ \\
\hline $\begin{array}{l}\text { Mouse mammary } \\
\text { epithelial cells } \\
\text { (HC11) }\end{array}$ & $\begin{array}{l}\text { Photolithography was used to create } \\
\text { grooves with depths of: } 40,110,200 \text { and } \\
400 \mathrm{~nm} \text { (these samples were termed } \\
\text { 'continuous' grooves. Colloidal } \\
\text { lithography was used to produce } \\
\text { nanofeatures on the grooves } 100 \mathrm{~nm} \\
\text { height and } 166 \mathrm{~nm} \text { diameter (these } \\
\text { samples were termed 'discontinuous' } \\
\text { grooves) }\end{array}$ & $\begin{array}{l}\text { - Quantitative morpho- } \\
\text { logical measurements } \\
\text { after fluorescent actin } \\
\text { staining }\end{array}$ & $\begin{array}{l}\text { Less cells adhered to, and aligned } \\
\text { along, the discontinuous grooves }\end{array}$ & $\begin{array}{l}\text { Andersson et al. } \\
(2003 b)\end{array}$ \\
\hline $\begin{array}{l}\text { Epithelial cells } \\
\text { (human bladder } \\
\text { carcinoma, HTB- } \\
\text { 4) }\end{array}$ & $\begin{array}{l}\text { Comparison of continuous grooves with } \\
184 \mathrm{~nm} \text { depth and nanohemispheres with } \\
167 \mathrm{~nm} \text { diameter and } 100 \mathrm{~nm} \text { height }\end{array}$ & $\begin{array}{l}\text { - Quantitative morpho- } \\
\text { logical measurements } \\
\text { after fluorescent actin } \\
\text { staining } \\
\text { - IL-6 and IL-8 cytokine } \\
\text { ELISA }\end{array}$ & $\begin{array}{l}\text { Compared to control, cells were } \\
\text { seen to become aligned on the } \\
\text { grooves, with no change in cytokine } \\
\text { production. On the samples } \\
\text { produced by colloidal lithography, } \\
\text { the cells were seen to become more } \\
\text { highly dispersed (more stellate) and } \\
\text { had decreased levels of IL-6 and } \\
\text { IL-8 production }\end{array}$ & $\begin{array}{l}\text { Andersson et al. } \\
(2003 \mathrm{c})\end{array}$ \\
\hline $\begin{array}{l}\text { Primary human } \\
\text { osteoblasts } \\
\text { (HOB).Primary } \\
\text { human } \\
\text { macrophages/ } \\
\text { monocytes }\end{array}$ & $\begin{array}{l}110 \mathrm{~nm} \text { high hemispheres with packing } \\
\text { densities of } 3,19,30 \text { and } 43 \% \text {. Whilst } \\
\text { colloids were used to make the features, } \\
\text { they were coated in a Ti thin film to } \\
\text { produce a single chemistry rather than } \\
\text { etched into polymer }\end{array}$ & $\begin{array}{l}\text { Quantitative morpho- } \\
\text { logical measurements } \\
\text { after fluorescent actin, } \\
\text { tubulin and fibronectin } \\
\text { staining }\end{array}$ & $\begin{array}{l}\text { Compared to tissue culture plastic, } \\
\text { the topography induced the release } \\
\text { of chemotactic macrophage } \\
\text { activation agents and caused stress } \\
\text { fibre and fibronectin formation from } \\
\text { the macrophages, The osteoblasts } \\
\text { were seen to simply migrate away } \\
\text { from the nanofeatures }\end{array}$ & Rice et al. (2003) \\
\hline $\begin{array}{l}\text { Human Fibroblast } \\
\text { (h-tert BJ1) }\end{array}$ & $160 \mathrm{~nm}$ high, $100 \mathrm{~nm}$ diameter columns & $\begin{array}{l}\text { - Cell adhesion after } 15 \text {, } \\
90 \text { and } 180 \text { mins } \\
\text { - Actin cytoskeleton after } \\
15,90 \text { and } 180 \text { mins } \\
\text { - Immunofluorescence of } \\
\text { actin, tubulin, vimentin } \\
\text { and vinculin } \\
\text { - SEM and TEM for } \\
\text { morphology }\end{array}$ & $\begin{array}{l}\text { Decreased cell adhesion and } \\
\text { spreading was observed for cells on } \\
\text { the nanocolumns. Actin and } \\
\text { vimentin cytoskeletons were less } \\
\text { well organised. Tubulin } \\
\text { cytoskeleton was well organised, } \\
\text { but there were less microtubules }\end{array}$ & $\begin{array}{l}\text { Dalby et al. } \\
\text { (2004a) }\end{array}$ \\
\hline $\begin{array}{l}\text { Human Fibroblast } \\
\text { (h-tert BJ1) }\end{array}$ & $160 \mathrm{~nm}$ high, $100 \mathrm{~nm}$ diameter columns & $\begin{array}{l}\text { - SEM and TEM for } \\
\text { morphology } \\
\text { - Actin, tubulin, vimentin } \\
\text { cytoskeleton } \\
\text { immunofluorescence } \\
\text { - Clathrin, dynamin and } \\
\text { Rac } \\
\text { immunofluorescence }\end{array}$ & $\begin{array}{l}\text { The cells attempted, but failed, to } \\
\text { endocytose the nanocolumns. Some } \\
\text { cells appeared to try and go further, } \\
\text { producing high levels of Rac at } \\
\text { sites of pseudopodia formation - } \\
\text { similar to those seen used by } \\
\text { macrophages for phagocytosis }\end{array}$ & $\begin{array}{l}\text { Dalby et al. } \\
\text { (2004b) }\end{array}$ \\
\hline $\begin{array}{l}\text { Human Fibroblast } \\
\text { (h-tert BJ1) }\end{array}$ & $160 \mathrm{~nm}$ high, $100 \mathrm{~nm}$ diameter columns & $\begin{array}{l}\text { - Quantitative } \\
\text { morphological } \\
\text { measurements after } \\
\text { Coomassie blue staining } \\
\text { - SEM and TEM } \\
\text { filopodial obervation } \\
\text { - Actin fluorescent } \\
\text { labelling }\end{array}$ & $\begin{array}{l}\text { Increased filopodial production was } \\
\text { noted on the nanocolumns. The } \\
\text { filopodia were regularly observed } \\
\text { to interact with the nanocolumns.- } \\
\text { The cells on the nanocolumns were } \\
\text { more stellate and less well spread }\end{array}$ & $\begin{array}{l}\text { Dalby et al. } \\
(2004 \mathrm{c})\end{array}$ \\
\hline
\end{tabular}


a surface then used as a template (Denis et al., 2002). The colloids were electrostatically self-assembled on a polymethylmethacrylate (PMMA) surface and used as an isotropic etch mask. As the colloids are removed by etching, so are areas of the surrounding polymer. The result is a surface of densely packed arrays of cylindrical nanocolumns.

Microarrays are a powerful biological tool in cell biology. They present a method of 'fishing' for changes by observing many gene regulations simultaneously. Thus, a logical progression from the morphological studies was to use 1718 gene microarray to monitor gene regulation within the human fibroblasts (h-tert BJ1) cultured on the nanocolumns. However, some caution must be applied to the interpretation of microarray data, and thus cell morphology has also been observed using light, electron and fluorescent microscopy.

\section{Material Fabrication \\ Materials and Methods.}

The starting substrate for fabrication of all samples was bulk oöymethylmethacrylate (PMMA). The PMMA substrates were precut into $8 \mathrm{~mm}$ by $8 \mathrm{~mm}$ squares using a diamond saw (Loadpoint, Swindon, UK). The $1 \mathrm{~mm}$ thick substrates were precut to a depth of $600 \mu \mathrm{m}$ from the backside. Colloidal lithography was used to modify the surface of the polymer producing nanostructured features. This approach is described in detail elsewhere (Denis et al., 2002), but in brief utilises electrostatically assembled dispersed monolayers of colloidal particles as masks for pattern transfer onto substrate materials. In this work the substrate materials were pretreated with a light oxygen plasma ( 0.25 Torr, 50 W RF, 120s) followed by electrostatic self-assembly of a multilayer of polyelectrolytes (poly(diallyldimethylammonium chloride) (PDDA, MW 200000-350000; Sigma-Aldrich, Gillingham, Dorset, UK), poly(sodium 4styrenesulfonate) (PSS, MW 70000, Sigma-Aldrich) and aluminium chloride hydroxide $(\mathrm{ACH}$; Reheis, Uxbridge, UK). Subsequent assembly of a colloidal mask (sulphate modified polystyrene colloid $107 \mathrm{~nm} \pm 5 \mathrm{~nm}$; Interfacial Dynamics Corp., now: Molecular Probes, Eugene, OR, USA) from aqueous solution followed by drying resulted in a dispersed colloidal monolayer which has short range order, but no long range order.

The pattern of the colloidal mask was transferred into the bulk polymer using a combination of vertical and angled argon ion bombardment $\left(250 \mathrm{eV}, 0.2 \mathrm{~mA} / \mathrm{cm}^{2}, 600 \mathrm{~s}\right.$ from 15 degrees from vertical followed by $840 \mathrm{~s}$ from vertical; Chemically Assisted Ion Beam Etching (CAIBE) Ion Beam System; Oxford Instruments (Oxford, U.K.) Ionfab), etching was continued until the particles were completely removed resulting in cylindrical pillars. Figure 1 shows an atomic force microscopy (AFM) height image of the resultant structures (tapping mode; Digital Instruments (now Veeco Instruments, Cambridge, U.K.) Dimension 3000, with a sharpened silicon oxide tip; NT-MDT, Moscow, Russia). During the etching process the surface of the polymer is oxidised and cross-linked with the argon ions penetrating only relatively short distances into the polymer and modifying only a thin outer layer $(5-7 \mathrm{~nm})$. Flat control substrates with matched surface chemistry (characterised by
X-ray fluorescence spectroscopy (XPS) data not shown here) were fabricated by subjecting flat PMMA substrates with no assembled particles to argon ion bombardment. The resultant surfaces had roughness levels around 3-5 $\mathrm{nm}$, as shown by AFM.

Samples for cell culture were snapped along pre-cut lines into $8 \mathrm{~mm}$ by $8 \mathrm{~mm}$ squares and blown with nitrogen to remove any particulate contamination and presterilised in $70 \%$ ethanol. Fabrication and pre-cleaning was carried out in a class 1000 clean room before packaging in airtight boxes for transfer. Finally samples were sterilised in $70 \%$ ethanol prior to use.

\section{Cell Culture}

Infinity $^{\mathrm{TM}}$ telomerase immortalised human fibroblasts (hTERT-BJ1, Clonetech Laboratories, Palo Alto, CA, USA) were seeded onto the test materials at a density of $1 \times 10^{4}$ cells per sample in $1 \mathrm{ml}$ of complete medium. These cells were selected as they are genetically stable and show closer phenotypical reactions to primary cells than transformed cells, but do not undergo senescence like primary cells. The medium used was $71 \%$ Dulbecco's Modified Eagle's Medium (DMEM) (SigmaAldrich), 17.5\% Medium 199 (Sigma-Aldrich), 9\% foetal calf serum (FCS) (Invitrogen Life Technologies, Paisley, UK), 1.6\% $200 \mathrm{mM}$ L-glutamine (Invitrogen Life Technologies) and $0.9 \% 100 \mathrm{mM}$ sodium pyruvate (Invitrogen Life Technologies). The cells were incubated at $37^{\circ} \mathrm{C}$ with a $5 \% \mathrm{CO}_{2}$ atmosphere, and the medium was changed twice a week.

\section{Quantification of Cell Area}

After three days of culture (to allow the viewing of individual cells), the cells were washed in phosphate buffered saline (PBS) and then fixed in 4\% formaldehyde / PBS for 15 minutes at $37^{\circ} \mathrm{C}$. The cells were then stained for 2 minutes in $0.5 \%$ Coomassie blue in a methanol / acetic acid aqueous solution, and washed with water to remove excess dye. Samples could then be observed by light microscopy, and digital images were captured using a Hamamatsu (Hamamatsu City, Japan) Argus 20 for image processing. For cell area quantification Image $\mathrm{J}$ was used (downloaded from the National Institute of Health, Bethesda, MD, USA- free download available at http://rsb.info.nih.gov/ij/). This used automated detection of cell outline and calculated the number of pixels covered by cells. Approximately 50 cells were counted on each material, and it should be noted that standardised illumination conditions were used throughout.

Student's t-test (for two samples, assuming unequal variances) was used to compare statistical significance of test materials against the flat. Results of $\mathrm{p}<0.01$ were considered significantly different from control (differences denoted by $* *$ ).

\section{RNA Expression Analysis}

Individual gene expression changes were detected by using spotted DNA microarrays. The arrays were printed with 1,718 distinct human transcripts obtained from the 
Ontario Cancer Institute Microarray Centre (http:// www.microarrays.ca). Complete protocols for the generation of fluorescence labelled samples from whole cell RNA, hybridisation to DNA microarrays and data processing can be found at this website.

In brief, cells were seeded at $1 \times 10^{4}$ cells $/ \mathrm{ml}$ and cultured up to approximately $90 \%$ confluency (10 days in culture) so as to allow sufficient quantities of RNA to be extracted. At this point, the cells were lysed and total RNA was extracted using a Qiagen RNeasy kit (Qiagen, Crawley, West Sussex, UK). The number of replicates used was 6 , but pairs were pooled to allow sufficient RNA extraction, thus giving 3 control and 3 test RNA extrudates. Measurement of RNA was performed at $1=260 \mathrm{~nm}$.

$2 \mu \mathrm{g}$ of RNA from each sample was used to make CY3or CY5- (Amersham Pharmacia, Amersham, UK) labelled cDNA using Superscript II reverse transcriptase with a poly-T mRNA primer (Gibco BRL; Invitrogen Life Technologies). For two of the arrays, the controls were labelled with CY5 and the test samples with CY3. For the third array, the controls were labelled with CY3 and the test samples with CY5. This reciprocal labelling ensures that the results are not artefacts of which dyes were used for the controls and samples (i.e. the results must be the same with each 'flip' in order to be accepted). Samples were prepared for hybridisation by combining fragmented salmon sperm DNA $(0.5 \mu \mathrm{g} / \mu \mathrm{l}$; Gibco BRL, UK) and yeast tRNA $(0.5 \mu \mathrm{g} / \mu \mathrm{l}$; Gibco BRL) in EasyHyb solution (Roche Diagnostics, Lewes, East Sussex, UK). Samples were hybridised for $16 \mathrm{~h}$ at $37^{\circ} \mathrm{C}$ onto three cDNA microarrays containing 1,718 known human expressed sequence tags. Arrays were next washed three times at room temperature with $0.1 \%(\mathrm{v} / \mathrm{v})$ saline sodium citrate (SSC) containing $0.1 \%(\mathrm{v} / \mathrm{v})$ sodium dodecyl sulfate (SDS) followed by one wash with $0.1 \%$ SSC alone.

Fluorescence intensities were captured using a Packard Scanarray Lite (Perkin Elmer, Boston, MA, USA) laser confocal scanner. Data was exported into a spread-sheet where the mean gene changes were calculated. Genes that exhibited a mean change of $\pm 100 \%$ were then fitted into the following headings for convenience: cytoskeleton, extracellular matrix, DNA transcription and translation and cell signalling.

\section{Transmission Electron Microscopy}

After 4 weeks of culture, the cells were fixed with $1.5 \%$ glutaraldehyde (Agar, Stansted, UK) buffered with $0.1 \mathrm{M}$ sodium cacodylate (Agar) for 1 hour. Cells were postfixed with $1 \%$ osmium tetroxide, dehydrated in a series of alcohols (70, 90, 96 and 100\%; sodium sulfate dried). Once dehydrated the samples were embedded in Spurr's resin (TAAB, Aldermaston, Berkshire, UK) and polymerised at $70^{\circ} \mathrm{C}$ for $18 \mathrm{~h}$. Ultrathin sections were cut, stained with uranyl acetate (2\% aq.) and lead citrate, and viewed with a Zeiss (Oberkochen, Germany) transmission electron microscope (TEM).

\section{Results and Discussion}

Colloidal lithography produced columns with an average height of $160 \mathrm{~nm}$, diameter of $100 \mathrm{~nm}$ and spacing of approximately $230 \mathrm{~nm}$ (Figure 1). Coomassie blue staining and image analysis of cell areas showed the fibroblasts to be less spread on the nano-columns compared to planar control (Figure 2).

Microarray data after fibroblast culture showed a number of shifts in gene expression. Table 2 shows the selected genes and briefly describes the function of the protein encoded by the gene, and how the production of the protein would affect a population of fibroblasts. Information on each gene of interest was found using gene bank numbers and the Stanford Source (http://genomewww5.stanford.edu/cgi-bin/SMD/source/sourceSearch (Diehn et al., 2003)).

The changes were predominantly down-regulation, which may be expected with less well spread fibroblasts. These down-regulations comprised a number of intracellular signalling proteins. Amongst these were a few small G-proteins. G-proteins have roles in the cytoskeletal conformation, formation and control of filopodia and lamellipodia, and control of proliferative genes. Tyrosine kinases, also down-regulated, interact with Ras G-proteins to stimulate cell proliferation and differentiation. These observations tie in well with observations of reduced cytoskeletal organisation and spreading (Dalby et al., 2004a,b). Rac is involved in the formation of lamellipodia, thus down-regulation of Rac ties in with a decrease in cell spreading on the nano-columns as cells use lamellapodia to spread and move (Spaargaren and Bos 1999; Sumi et al., 1999; Scaife et al., 2000; Katoh et al., 2001a,b).

Rac immunostaining (Figure 2) shows the Rac distribution in a well spread cell on control and a less spread cell on the nanocolumns. Whilst the way that Rac is distributed looks similar, due to the small size of the cells on the nanocolumns, it appears that there is simply less Rac present (however, Rac enrichment at the sites of lammelipodia formation is clear in cells on the nanocolumns). This ties in well with the microarray result.

Alpha-actinin was also down-regulated and is involved in the formation of lamellipodia by cross-linking actin microfilaments. Cell spreading and the formation of filopodia is related to the cells ability to develop a wellorganised cytoskeleton. Rhodamine-phalloidin staining of actin microfilaments (Figure 3 ) shows that compared to the well-developed cytoskeleton observed in fibroblasts on the planar controls, cells on the nanocolumns had a rather punctate actin organisation, typical of poorly spread cells, with many filopodia, typical of cells on topography 'sensing' their surroundings (Dalby et al., 2004e). Again, these results back up the microarray data and are consistent with cells where actin cross-linking is decreased.

An interplay of up- and down- regulation was seen for the inter-cellular cytokine signalling proteins. Up-regulated were cytokine receptor class II (CRF2-4), transforming growth factor alpha (TGF-a) and tumor necrosis factor (TNF) receptor 2. Down-regulated were Insulin-like growth factor binding protein 1 (IGFBP-1), alpha plateletderived growth factor (aPDGF) receptor. Bone morphogenic protein (BMP) receptor IA also acts as an 
Table 2. Table of altered genes and their functions in fibroblast populations. This Table expands on Figure 2 by briefly explaining the role of the protein product of the changed genes.

Up-regulations

\begin{tabular}{|l|l|}
\hline \multicolumn{1}{|c|}{ Gene name } & \multicolumn{1}{|c|}{ function in fibroblasts } \\
\hline CYTOKINE RECEPTOR CLASS-II CRF2-4 PRECURSOR & $\begin{array}{l}\text { Cell-cell signalling - notably for interferon - } \\
\text { Effects cytoskeleton and stimulates differentiation- } \\
\text { (IFNo, IFN }, \text { IFN } \gamma \text { ) and several ILs (IL-10 and } \\
\text { IL-TIF (T-cell derived inducible factor) - } \\
\text { inflammation regulation) }\end{array}$ \\
\hline TRANSFORMING GROWTH FACTOR ALPHA PRECURSOR (TGF-ALPHA) & Wound healing and cell differentiation \\
\hline TRANSCRIPTION INITIATION FACTOR TFIID & Proliferation \\
\hline TUMOR NECROSIS FACTOR RECEPTOR 2 PRECURSOR & ECM remodelling via IL-1 \\
\hline KERATIN, TYPE I CYTOSKELETAL 18 (CYTOKERATIN 18) & Possible cell differentiation \\
\hline
\end{tabular}

Down-regulations

\begin{tabular}{|c|c|}
\hline Gene name & function in fibroblasts \\
\hline CELLULAR APOPTOSIS SUSCEPTIBILITY PROTEIN & Reduced cell apoptosis \\
\hline RAC-ALPHA SERINE/THREONINE KINASE & Signal transduction \\
\hline INTERFERON REGULATORY FACTOR 1 & Effects cytoskeleton and stimulates differentiation \\
\hline PROTEIN KINASE C & Signal transduction \\
\hline $\begin{array}{l}\text { INSULIN-LIKE GROWTH FACTOR BINDING PROTEIN } 1 \text { PRECURSOR } \\
\text { (IGFBP-1) }\end{array}$ & Collagen regulation \\
\hline RAS-RELATED C3 BOTULINUM TOXIN SUBSTRATE 3 (P21-RAC3) & Signal transduction \\
\hline DNA-DIRECTED RNA POLYMERASE II 16 KD POLYPEPTIDE & Proliferation \\
\hline TYROSINE-PROTEIN KINASE RYK PRECURSOR & Signal transduction \\
\hline CHLORIDE CHANNEL PROTEIN 2 (CLC-2) & Signal transduction \\
\hline REPLICATION PROTEIN A 32 KD SUBUNIT & proliferation \\
\hline ALPHA PLATELET-DERIVED GROWTH FACTOR RECEPTOR PRECURSOR & $\begin{array}{l}\text { Chemotaxis, also effect proliferation in } \\
\text { conjunction with TGF } \beta\end{array}$ \\
\hline GUANINE NUCLEOTIDE-BINDING PROTEIN G(O), ALPHA SUBUNIT 1 & Proliferation \\
\hline ALPHA-ACTININ 2 (F-ACTIN CROSS LINKING PROTEIN) & Cytoskeleton \\
\hline RECEPTOR PROTEIN-TYROSINE KINASE TKT PRECURSOR & Signal transduction \\
\hline PROCOLLAGEN ALPHA 1(IV) CHAIN PRECURSOR & ECM \\
\hline $\begin{array}{l}\text { BONE MORPHOGENETIC PROTEIN RECEPTOR TYPE IA PRECURSOR } \\
\text { (BMP 1) }\end{array}$ & $\begin{array}{l}\text { Metalloproteinase that effects mesenchymal } \\
\text { differentiation }\end{array}$ \\
\hline PROBABLE G PROTEIN-COUPLED RECEPTOR GPR13 & Signal transduction \\
\hline CHLORIDE INTRACELLULAR CHANNEL PROTEIN 2 (XAP121) & Signal transduction \\
\hline APOPTOSIS REGULATOR BCL-2 & Regulates apoptosis \\
\hline ACTIVATED RNA POLYMERASE II TRANSCRIPTIONAL COACTIVATOR P15 & Proliferation \\
\hline ZINC FINGER PROTEIN 35 & Proliferation \\
\hline
\end{tabular}

inter-cellular signalling protein and was down-regulated. As shown in Table 2, these proteins influence fibroblast proliferation and differentiation and will be important in the development of new tissue (Bagutti et al., 2001; Takashiba et al., 2003; see review by Atamas, 2002 for good discussion of effects of cytokines on fibroblasts). As discussed in the introduction cytokine release (IL-6 and
IL-8) have previously been flagged as important in epithelial cells (Andersson et al., 2003c).

A number of transcription factors and genes involved with proliferation were also shown to be down-regulated (Table 2). Figure 4 shows electron microscopy sections of fibroblasts on the flat and nanostructured substrates. After 4 weeks on the control samples, the fibroblasts had formed 


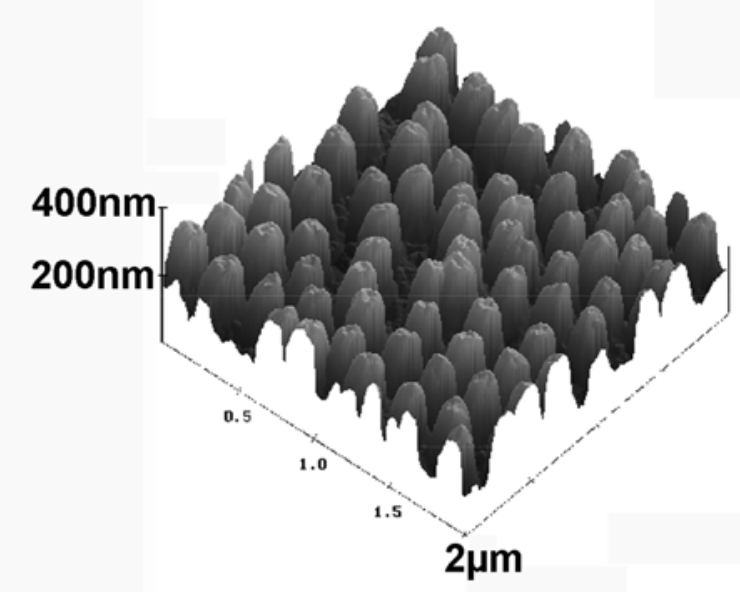

Figure 1. Atomic force microscopy image of the 160 nm high nanocolumns.

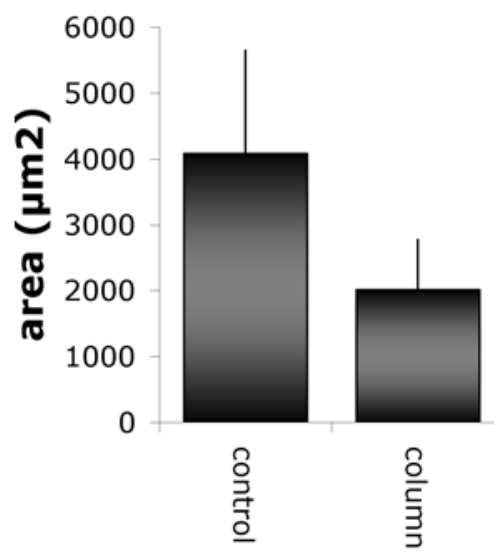

Figure 2. Graph showing cell areas for fibroblasts cultured on controls and the nanocolumns. The cells on the nanocolumns were significantly less well spread. Results are the mean \pm standard deviation, $* *=\mathrm{t}$-test $\mathrm{p}<0.01$.
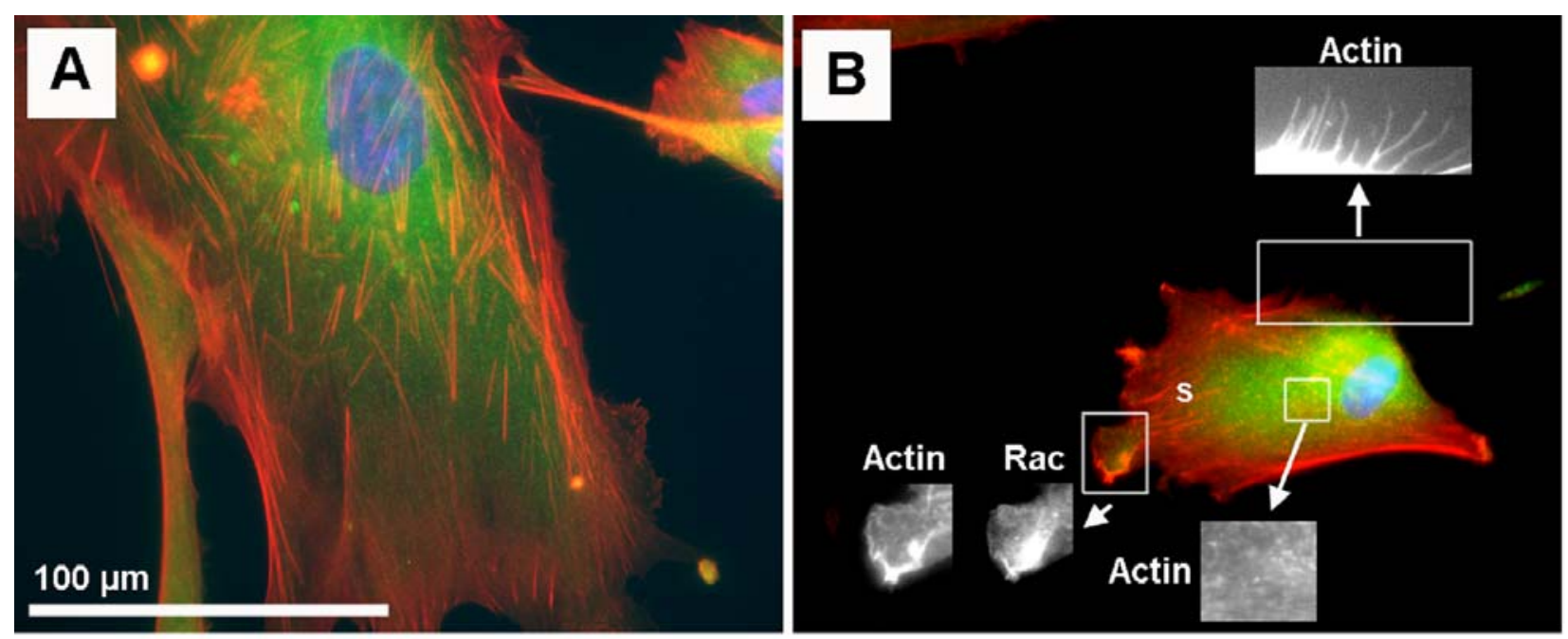

Figure 3. Fluorescent observation of actin (red), Rac (green) and cell nuclei (blue). (A) Fibroblast on planar control, the cell is well spread with many stress fibres and diffuse Rac. (B) Fibroblast on nanocolumns, the cell is less well spread with many filopodia (top inset), generally punctate actin (bottom inset) with few stress fibres (s) and actin and Rac co-localisation in lamellipodia (left inset).

multi-layers of cells, whereas on the nanocolumns, the cells were just a monolayer thick. This is concurrent with the microarray observation of proliferative gene downregulation. These results also agree with TEM images from Dalby et al. (2004a).

\section{Conclusion}

The results from the microarrays have allowed us to sift through a large number of genes (1718) simultaneously. The changes noted were much smaller than those that have been previously observed on microtopography. This might be expected as microscale topography produced much larger changes in cell shape (such as contact guidance in grooves (Clark et al., 1987) or trapping in pits (Berry et al., 2004)), whereas the colloidal nanotopography only results in a decrease in cell spreading.
There has been a wealth of publication on cell responses to topography produced by colloidal lithography from this lab (Dalby et al., 2004a,b,c) and by other groups (Andersson et al., 2003a,b,c; Rice et al., 2003). Comparison of these results and results on other topographies such as polymer demixed nanoislands (Dalby et al., 2002a,b) and electron beam lithographical (EBL) surfaces (Gallagher et al., 2002; Dalby et al., 2004e) shows that cells are highly responsive to nanotopography with EBL nanopits and colloidal nanocolumns reducing adhesion and more gentle nanoislands increasing adhesion. By increasing and reducing the feature shapes intermediate control can also be gained (see Dalby et al., 2002a,b, 2004e which change EBL pit size and polymer demixed island diameter). The ability to control cell adhesion and response is desirable in cell engineering and suggests that nanotopography will have an important role in the development of next-generation materials. 


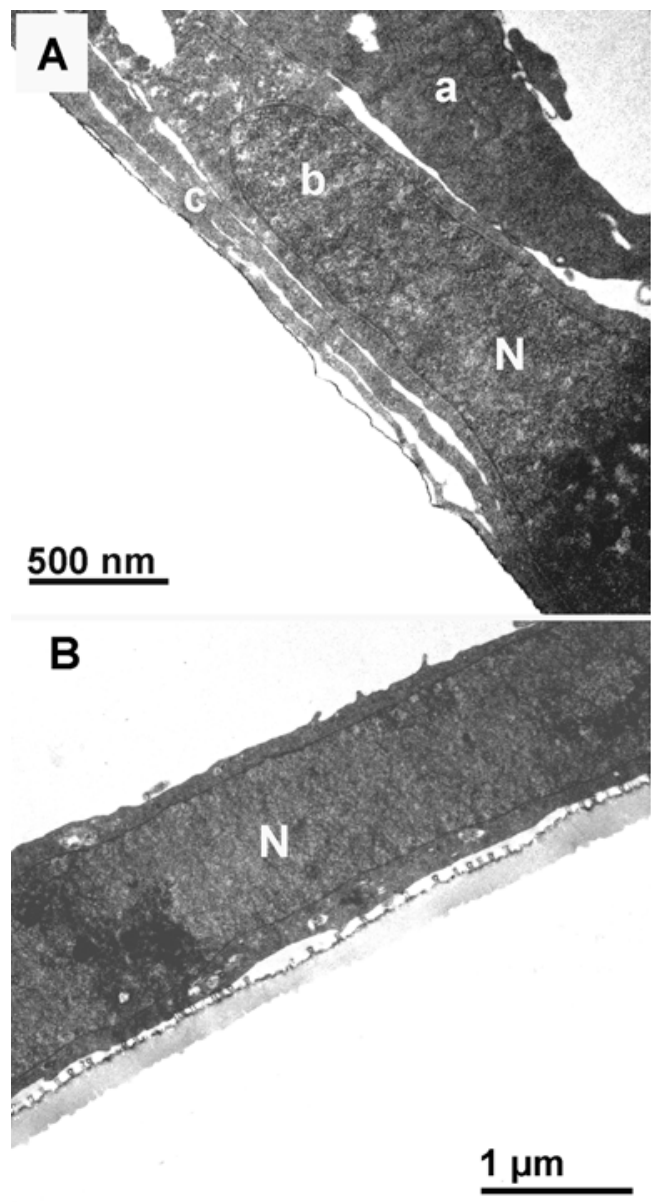

Figure 4. TEM images for cells cultured on (A) planar control with three cell layers $(a, b, c)$ and $(B)$ nanocolums with a cell monolayer. $\mathrm{N}=$ nucleus.

\section{Acknowledgements}

M. Dalby is a BBSRC David Phillips Fellow and is funded through this route. This work was supported by the EU framework V grant QLK3-CT-2000-01500 (Nanomed). We would also like to thank Prof. C. Wilkinson for his discussion and Dr L. Tetley, Mrs M. Mullin and Mr Ioin Robertson at the IBLS Integrated Microscopy Facility for much appreciated help with electron microscopy.

\section{References}

Andersson AS, Bäckhed F, von Euler A., RichterDahlfors A, Sutherland DS, Kasemo B (2003a) Nanoscale features influence epithelial cell morphology and cytokine production. Biomaterials 24: 3427-3436.

Andersson A-S, Olsson P, Lidberg U, Sutherland DS (2003b) The Effects of Discontinuous and Continuous Groove Edges on Cell Shape and Alignment. Exp Cell Res 288: $177-188$.

Andersson A-S, Brink J, Lidberg U, Sutherland DS (2003c) Influence of systematically varied nanoscale topography on the morphology of epithelial cells. IEEE Trans Nanobiosci 2, 49-57.
Atamas SP (2002). Complex cytokine regulation of tissue fibrosis. Life Sci 72: 631-643.

Bagutti C, Hutter C, Chiquet-Ehrismann R, Fassler R, Watt F M (2001) Dermal fibroblast-derived growth factors restore the ability of beta(1) integrin-deficient embryonal stem cells to differentiate into keratinocytes. Dev Biol 23: 321-333.

Berry CC, Campbell G, Spadiccino A, Robertson M, Curtis ASG (2004) The influence of microscale topography on fibroblast attachment and motility. Biomaterials 25: 5781-5788.

Britland S, Morgan H, Wojciack-Stothard B, Riehle M, Curtis A, Wilkinson C (1996) Synergistic and hierarchical adhesive and topographic guidance of BHK cells. Exp Cell Res 228: 313-325.

Carrel A, Burrows M (1911) Culture in vitro of malignant tumors. J Exp Med 13: 571-575.

Chen CS, Mrksich M, Huang S, Whitesides GM, Ingber DE (1997) Geometric control of cell life and death. Science 276: $1425-1428$.

Clark P, Connoly P, Curtis ASG, Dow JAT, Wilkinson CDW (1987) Topographical control of cell behaviour: Simple step cues. Development 99: 439-448.

Clark P, Connoly P, Curtis ASG, Dow JAT, Wilkinson CDW (1990) Topographical control of cell behaviour: II. Multiple grooved substrata. Development 108: 635-644.

Dalby MJ, Riehle MO, Johnstone H, Affrossman S, Curtis ASG (2002a) In vitro reaction of endothelial cells to polymer demixed nano-topography. Biomaterials 23: 2945-2954.

Dalby MJ, Riehle MO, Johnstone HJH, Affrossman S, Curtis ASG (2002b) Polymer demixed nano-topography: control of fibroblast spreading and proliferation. Tissue Eng 8: 1099-1108.

Dalby MJ, Yarwood SJ, Riehle MO, Johnstone H, Affrossman S, Curtis ASG (2002c) Increasing fibroblast response to materials using nanotopography: Morphological and genetic measurements of cell response to $13 \mathrm{~nm}$ high polymer demixed islands. Exp Cell Res 276: $1-9$.

Dalby MJ, Riehle MO, Yarwood SJ, Wilkinson CDW, Curtis ASG (2003) Nucleus alignment and cell signalling in fibroblasts: Response to a micro-grooved topography. Exp Cell Res 283: 274-282.

Dalby MJ, Riehle MO, Sutherland DS, Agheli H, Curtis ASG (2004a) Fibroblast response to a controlled nanoenvironment produced by colloidal lithography. J Biomed Mater Res 69A: 314-322.

Dalby MJ, Berry CC, Riehle MO, Sutherland DS, Agheli H, Curtis ASG (2004b). Attempted endocytosis of nano-environment produced by colloidal lithography by human fibroblasts. Exp Cell Res 295: 387-394.

Dalby MJ, Riehle MO, Sutherland DS, Agheli H, Curtis ASG. (2004c) Changes in fibroblast morphology in response to nano-columns produced by colloidal lithography. Biomaterials 25: 5415-5422.

Dalby MJ, Riehle MO, Sutherland DS, Agheli H, Curtis ASG. (2004d). Use of nano-topography to study mechanotransduction in fibroblasts - methods and perspectives. Eur J Cell Biol 83: 159-169. 
Dalby MJ, Gadegaard N, Riehle MO, Wilkinson CDW, Curtis ASG (2004e) Investigating filopodia sensing using arrays of defined nano-pits down to $35 \mathrm{~nm}$ diameter in size. Int J Biochem Cell Biol 36: 2005-2015.

Denis FA, Hanarp P, Sutherland DS, Dufrêne YF (2002) Fabrication of nanostructured polymer surfaces using colloidal lithography and spin-coating. Nanoletters 2: 1419-1425.

Diehn M, Sherlock G, Binkley G, Jin H, Matese JC, Hernandez-Boussard T, Rees CA, Cherry JM, Botstein D, Brown PO, Alizadeh AA (2003) SOURCE: a unified genomic resource of functional annotations, ontologies, and gene expression data. Nucl Acids Res. 31: 219-223.

Gallagher JO, McGhee KF, Wilkinson CDW, Riehle MO (2002) Interaction of animal cells with ordered nanotopography. IEEE Trans Nanobiosci 1: 24-28.

Katoh K, Kano Y, Amano M, Onishi H, Kaibuchi K Fujiwara K (2001) Rho kinase mediated contraction of isolated stress fibres. J Cell Biol 153: 568-584.

Rice JM, Hunt JA, Gallagher JA, Hanarp P, Sutherland DS, Gold J (2003) Quantitative assessment of the response of primary derived human osteoblasts and macrophages to a range of nanotopography surfaces in a single culture model in vitro. Biomaterials 24: 4799-4818.

Sumi T, Matsumoto K, Takai Y, Nakamura T (1999) Cofilin phosphorylation and actin cytoskeletal dynamics regulated by rho and Cdc42 activated LIM-kinase 2. J Cell Biol 147: 1519-1532.

Spaargaren M, Bos JL (1999) Rab5 induces Rac dependent lamellipodia formation and cell migration. Mol Biol Cell 10: 3239-3250.

Scaife RM, Langdon WY (2000) c-Cbl localizes to actin lamellae and regulates lamellipodia formation and cell morphology. J. Cell Sci 113: 215-226.

Takashiba S, Naruishi K, Murayama Y (2003) Perspective of cytokine regulation for periodontal treatment: fibroblast biology. J Periodontol 74: 103-110.

Weiss P, Garber B (1952). Shape and movement of mesenchyme cells as functions of the physical structure of the medium. Proc Natl Acad Sci USA 38: 264-280.

Wojciack-Stothard B, Madeja Z, Korohoda W, Curtis A, Wilkinson W (1995) Activation of macrophage-like cells by multiple grooved substrata. Topographical control of cell behaviour. Cell Biology Int 19: 485-490.

Wood MA, Meredith DO, Owen GRh (2002) Steps towards a model nanotopography. IEEE Trans. Nanobiosci 1: $133-140$.

\section{Discussion with Reviewers}

Reviewer 1: All data is reported as an up-regulation or down-regulation of a select gene expression with reference to how the cells behaved on the flat PMMA controls. Relative to what external reference since PMMA is not a typical cell culture support? Where is the appropriate control for this experiment? This reviewer questions whether the authors should have also compared the gene expression to standard tissue culture polystyrene as general references. This reviewer understands that the work was designed to show an effect due to surface topography. However, for general acceptance and relevance, please clarify your use of PMMA only. When doing any type of cell culture experiment, since cells are originally proliferated on TCPS, an appropriate control is TCPS in addition to any experimental specific controls. Please comment.

Authors: In many cases, it is true that tissue culture plastic - or perhaps the more widely used control, Thermanox ${ }^{\mathrm{TM}}$, would be the accepted control material. However, in this case we felt that if we were to use Thermanox ${ }^{\mathrm{TM}}$, then it would bear no chemical similarity to the test materials (nanofabricated PMMA that had been etched). Thus, we opted to use ultra-smooth and etched PMMA as this was not only flat, but also chemically identical to the test materials.

Reviewer2: The entire microarray field is in fact in some 'disarray' over the handling of these data and their arbitrary and often irreproducible nature (see several recent Science and Nature features on this problem, and many other reviews).

Authors: Indeed it is. Here, we have tried to use traditional microscopy to confirm microarray results - that way, we can look at G-proteins - such as Rac - by array and cytoskeletons - such as actin and tubulin - by immunolabelling and proliferation by observation of cell growth by e.g. TEM. We appreciate that traditionally, quantitative PCR is used to confirm data, but we feel that histology can provide a good alternative. We also feel that histology can be used to describe several cell events simultaneously and thus, perhaps, give more information that PCR. 